\title{
ANALISIS REKOMENDASI PRODUK MENGGUNAKAN ALGORITMA ECLAT BERDASARKAN RIWAYAT DATA PENJUALAN PT XYZ
}

\author{
AuzanWidyan'), Anief Fauzan Rozi ${ }^{2)}$ \\ ${ }^{1,2}$ Fakultas Teknologi Informasi, Universitas Mercu Buana Yogyakarta, J1. Jembatan Merah No. 84C Gejayan, \\ Yogyakarta 55283, Indonesia \\ email: ${ }^{1}$ auzanwidyan@gmail.com \\ email: ªnief@mercubuana-yogya.ac.id
}

\begin{abstract}
Abstrak
PT XYZ merupakan perusahaan yang menyediakan sarana produksi peternakan. Tranksaksi penjualan dicatat sebagai arsip perusahaan, laporan penjualan, dan laporan laba rugi. Lebih dari 1.500 lembar faktur tercetak setiap bulan. Namun, dalam hal promosi produk, belum menggunakan hasil analisis dari riwayat transaksi penjualan. Penelitian ini bertujuan untuk memberikan rekomendasi produk menggunakan algoritma ECLAT. Algoritma ECLAT (Equivalence Class Transformation) menggunakan konsep pencarian depth-first untuk menemukan itemset yang sering muncul dalam transaksi. Langkah penelitian, yaitu wawancara untuk akuisisi data, pra-pemrosesan data, transformasi data, dan proses data mining dengan algoritma ECLAT untuk menemukan frequent itemset dan menggunakan hasil frequent itemset sebagai basis pembuatan pola aturan asosiasi. Hasil analisis menujukkan bahwa sistem dapat memberikan rekomendasi aturan asosiasi secara efektif dari 14.617 riwayat transaksi. Minimum support tertinggi yang dapat digunakan untuk menemukan kombinasi k-itemset adalah 1\%. Hasil aturan asosiasi pertahun dari riwayat transaksi tahun 20182020 menunjukkan perbedaan hasil dengan ragam terbanyak terjadi tahun 2020, yaitu 5 aturan asosiasi. Setiap aturan asosiasi yang muncul memiliki nilai confidence yang kuat yakni di atas $50 \%$.
\end{abstract}

Kata Kunci: Rekomendasi Produk, KDD, Data Mining, Algoritma ECLAT, Aturan Asosiasi.

\begin{abstract}
PT XYZ is a company that provides livestock production facilities. Sales transactions are recorded as company files, sales reports, and income statements. More than 1,500 invoices are printed every month. However, in terms of product promotion, the company have not used the analysis results from the history of sales transactions. This study aims to provide product recommendations using the ECLAT algorithm. The ECLAT (Equivalence Class Transformation) algorithm uses the concept of depth-first search to find itemsets that often appear in transactions. The research steps are interviews for data acquisition, data pre-processing, data transformation, and data mining process with the ECLAT algorithm to find frequent itemsets and use the frequent itemset results as the basis for making association rules patterns. The results of the analysis show that the system can provide recommendations for association rules effectively from 14,617 transaction history. The highest minimum support that can be used to find a combination of $k$-itemset is $1 \%$. The results of the annual association rules from the transaction history in 2018-2020 show the difference in results with the highest variance occurring in 2020, namely 5 association rules. Each association rule that appears has a strong confidence value that is above $50 \%$.
\end{abstract}


Keywords: Product Recommendations, KDD, Data Mining, ECLAT Algorithm, Association Rules.

\section{PENDAHULUAN}

PT XYZ merupakan perusahaan yang bergerak dalam industri peternakan dengan fokus utama sebagai perusahaan jual-beli yang menyediakan sarana produksi peternakan (sapronak), yang meliputi berbagai macam OVK (Obatobatan, Vaksin, dan Kimia), makanan ternak, jasa pelayanan kesehatan ternak, dan juga perdagangan umum. Data riwayat transaksi PT XYZ belum dimanfaatkan secara baik untuk meningkatkan potensi pemasaran. Berdasarkan wawancara dengan salah satu pegawai PT XYZ, lebih sering ditemukan bahwa pegawai PT XYZ hanya berfokus untuk merekomendasikan barang yang sedang dalam masa promosi atau berfokus pada barang yang supliernya bekerjasama dengan PT XYZ untuk mengejar insentif yang diterima pegawai, sedangkan dari laporan transaksi ditemukan bahwa pelanggan lebih tertarik terhadap produk-produk tertentu [1].

Selain digunakan sebagai arsip perusahaan, data transaksi penjualan PT XYZ juga diolah menjadi laporan penjualan dan laporan laba rugi. Data transaksi penjualan juga menjadi patokan target penjualan bulan selanjutnya. Namun, dalam hal promosi produk PT $\mathrm{XYZ}$ belum menggunakan hasil analisa dari riwayat transaksi penjualan. Hal ini mengakibatkan kurang tercapainya target penjualan yang diharapkan sehingga perusahaan tidak medapatkan keuntungan yang maksimal [1].
Perlu dilakukan terobosan baru sehingga perusahaan mendapatkan keuntungan maksimal. Salah satu langkah yang dapat ditempuh adalah dengan strategi pemasaran. Strategi pemasaran bertujuan untuk mempengaruhi pembeli untuk membeli jasa dan produk yang dibuat atau disediakan oleh pemasar saat mereka membutuhkannya. Kebutuhan dan keinginan pembeli sangat berfluktuasi dan dapat berubah karena komponen yang mempengaruhi pembeli dalam melakukan pembelian. Selanjutnya, pemasar perlu memahami perilaku pelanggan agar aktifitas kampanye pemasaran yang dilakukan dapat menghasilkan dampak yang sesuai dengan rencana produktif [2].

Pola pembelian pelanggan merupakan salah satu perilaku pelanggan yang dapat diamati. Pola pembelian adalah kegiatan berulang yang rumit. Terdiri dari beberapa unsur yang jelas dan runtut yang dilakukan oleh pelanggan ketika membeli barang. Perilaku pembelian tidak hanya dilihat dari berulangnya pembelian dan pengeluaran normal yang dikeluarkan saat membeli, tetapi juga dari profil individu pelanggan [3]. Berdasarkan pernyataan tersebut, maka dapat disimpulkan bahwa pola pembelian pelanggan juga dapat dilihat melalui riwayat transaksi penjualan.

Market basket analysis merupakan konsep dalam data mining yang berusaha menemukan asosiasi atau keterkaitan data. Pada awal ditemukannya, konsep ini berkaitan dengan barang-barang yang 
berada didalam keranjang belanja yang secara langsung menunjukan tingkah laku pelanggan saat berbelanja [4]. Pemanfaatan data mining dengan konsep market basket analysis dianggap cocok untuk mengatasi masalah sektor penjualan PT XYZ yang mengalami kendala dalam memberikan rekomendasi produk yang sesuai untuk pelanggan. Market basket analyis pernah digunakan oleh Sulastri, Zuliastro, dan Anis pada tahun 2017 untuk mengetahui informasi produk dan jasa yang sering terjual berdasarkan temuan pola transaksi pelanggan bengkel sepeda motor merk Honda. Penelitian menunjukkan hasil yang berbeda antara algoritma apriori dengan ECLAT. Analisis asosiasi dengan menggunakan algoritma apriori terhadap data transaksi menghasilkan dua aturan. Sedangkan analisis asosiasi dengan menggunakan algoritma ECLAT menghasilkan satu aturan. Berdasarkan tiga aturan yang ditemukan tersebut, maka pihak manajemen bengkel dapat melakukan strategi pemasaran terhadap barang dan jasa yang harus disediakan sehingga menghasilkan pelayanan yang optimal bagi pelanggan bengkel [5].

Penelitian serupa juga dilakukan oleh Wijaya pada tahun 2020 dengan membandingkan algoritma FP-Growth dengan ECLAT pada minimarket. Dibanding algoritma apriori, algoritma FP-Growth memiliki waktu pemrosesan yang relatif lebih singkat dalam menemukan frequent itemset. Sedangkan algoritma ECLAT merupakan algoritma yang memanfaatkan konsep pencarian depth-first dan menggunakan basis data yang tersusun secara vertikal. Hasil uji perbandingan kedua algoritma menunjukan bahwa algoritma ECLAT unggul dalam segi kecepatan dibanding algoritma FP-growth. Algoritma ECLAT hanya membutuhkan waktu 12 detik dan menghasilkan jumlah aturan sebanyak 14 aturan pada nilai support 0.01 dan confidence 0.85 [6].

\section{KAJIAN PUSTAKA}

\subsection{Produk}

Produk adalah sesuatu yang diperoleh, dibuat, dikembangkan, dijual dan dimanfaatkan atau dimiliki untuk memenuhi keinginan atau kebutuhan sehingga dipasarkan agar mencapai tujuan yang diharapkan. Segala hal yang dipasarkan, termasuk benda dalam bentuk fisik, jasa yang ditawarkan seseorang, sebuah tempat atau lokasi, badan organisasi atau perkumpulan, serta ide atau gagasan merupakan bentuk luas dari suatu produk [7, hal. 207]. Produk dapat dikelompokkan kedalam tiga jenis [8, hal. 252], yaitu :

1. Berdasarkan wujudnya, yaitu produk barang dan jasa.

2. Berdasarkan daya tahannya, yaitu produk dengan daya tahan lama dan tidak tahan lama

3. Berdasarkan tujuan penggunaanya, yaitu barang konsumsi dan barang produksi.

\subsection{Sarana Produksi Peternakan}


Produk untuk peternakan merupakan satu produk yang dibutuhkan oleh manusia. Ternak merupakan istilah untuk hewan atau binatang yang dibudidayakan manusia untuk memenuhi kebutuhan, sedangkan kegiatan memelihara salah satu jenis atau lebih hewan atau binatang untuk dikembangbiakkan sehingga mendapatkan keuntungan disebut peternakan [9, hal. 27]. Selain pada pemeliharaan, tujuan peternakan adalah untuk mengoptimalkan perpaduan antar faktor produksi dengan menerapkan prinsip manajemen untuk memaksimalkan keuntungan. Terdapat dua golongan kegiatan di bidang peternakan, meliputi peternakan hewan besar seperti babi, kambing, kuda, kerbau dan sapi. Golongan kedua meliputi peternakan hewan kecil seperti unggas, kelinci, lebah, dan lain sebagainya [10, hal. 37].

Dari pengertian-pengertian yang telah dijelaskan di atas, maka dapat diperoleh kesimpulan bahwa sarana produksi peternakan (sapronak) merupakan seluruh fasilitas atau peralatan pada peternakan yang diperlukan baik yang bergerak maupun yang tidak bergerak untuk menciptakan atau menambah manfaatnya dalam bidang ekonomi. Dalam hal ini, fasilitas atau pun peralatan yang dimaksudkan berupa pakan ternak, obatobatan untuk ternak yang meliputi vaksin, dan kimia, serta produk yang berupa jasa meliputi penyuluh lapangan, dukungan teknis, dokter hewan dan vaksinator.

\subsection{Market Base Analysis (Association Rules)}

Market basket analysis merupakan salah satu bentuk teknik pengaplikasian data mining di bidang pemasaran dan bisnis. Market basket analysis merupakan konsep dalam data mining yang berusaha menemukan asosiasi atau keterkaitan data [4, hal. 5]. Pada awal ditemukannya, konsep ini berkatian dengan barangbarang yang berada di dalam keranjang belanja yang secara langsung menunjukkan tingkah laku konsumen saat berbelanja. Association rule merupakan metode yang digunakan untuk menemukan pola antar item yang sering muncul dalam transaksi-transaksi yang terjadi dan setiap transaksi tersebut terdiri dari beberapa item [11]. Metodologi ini menggunakan dua parameter yaitu support dan confidence. Parameter Support merupakan persentasi seberapa banyak kombinasi item yang ditemukan di dalam basis data sedangkan confidence merupakan kuatnya hubungan satu item dengan item lainnya didalam asosiation rule yang terbentuk. Hasil dari kombinasi item yang terbentu dan memenuhi syarat support minimal dan confidence minimal disebut daftar aturan asosiasi [6, hal. 367]. Rumus untuk menghitung nilai support dari satu item adalah seperti berikut:

$\operatorname{Support}(A)=\frac{\sum \text { Transaksi } A}{\sum \text { Transaksi }} \times 100 \%$

Sedangkan untuk menghitung nilai support dari dua item atau lebih menggunakan rumus berikut:

Support $(A B)=P(A \cap B)$

Support $(A B)=\frac{\sum \text { Transaksi } A \& B}{\sum \text { Transaksi }} \times 100 \%$ 
Nilai Support dari A dan B adalah jumlah keseluruhan transaksi yang mengandung item $\mathrm{A}$ dan $\mathrm{B}$ dibagi dengan total transaksi lalu dikali dengan 100 persen. Rumus untuk menghitung nilai minimum confidence dengan adalah seperti berikut:

$$
\begin{aligned}
& \text { Confidence }(A \rightarrow B)=P(A \mid B) \\
& \text { Confidence }(A \rightarrow B)=\frac{\sum \text { Transaksi } A \& B}{\sum \text { Transaksi } A} \times 100 \%
\end{aligned}
$$

Nilai confidence $(A \rightarrow B)$ atau $\operatorname{Kepastian}(\mathrm{A} \rightarrow \mathrm{B}) \quad$ diperoleh dengan membagi hasil nilai support dari A dan B dengan nilai support dari A dikali dengan 100 persen.

\section{METODE PENELITIAN}

Jalan penelitian bertujuan untuk membuat target yang hendak dicapai dalam penelitian secara keseluruhan berjalan dengan baik sesuai apa yang direncanakan atau dikehendaki sehingga proses dan tujuan dari penelitian tersebut dalam memecahkan masalah bisa berjalan dengan baik pula serta jelas dan terstruktur. Pada Gambar 1. menjelaskan tentang langkah-langkah diagram alir rancangan penelitian secara singkat dari awal hingga akhir.

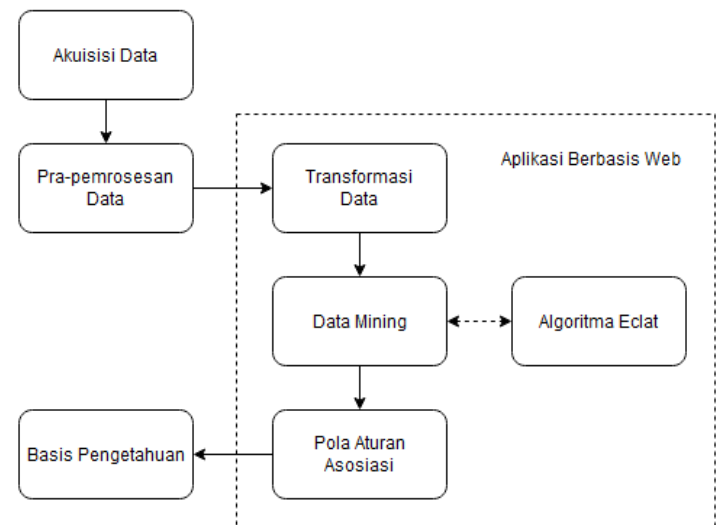

Gambar 1. Jalan Penelitian

Penelitian ini merupakan kuantitatif yang menerapkan konsep Knowledge Discovery In Database atau KDD. KDD merupakan runtutan aktifitas yang penting untuk menemukan dan mengidentifkasi pola dari sekumpulan besar data. Data yang dimaksud adalah sekumpulan fakta atau dalam situasi ini berupa sebuah basis data dan pola yang ditemukan bersifat meyakinkan, baru, memiliki manfaat dan bisa dimengerti [12, hal. 41]. Sehingga dapat diartikan KDD merupakan tindakan untuk mengambil pengetahuan yang penting dalam bentuk pola dari database yang besar.

\subsection{Akuisisi Data}

Wawancara dilakukan untuk mendapatkan data yang berhubungan dengan analisis rekomendasi produk PT XYZ dengan cara mewawancarai staf dan kasir PT XYZ cabang Kademangan. Wawancara dilakukan selama periode 3 24 Mei 2021. Studi dokumen dilakukan dengan memanfaatkan dokumen riwayat transaksi penjualan dari PT XYZ cabang Kademangan sebagai sumber data utama 
penelitian. Dokumen yang dipilih merupakan transaksi pada tahun 2018 2020.

\subsection{Pra-pemrosesan Data}

Pada tahap pra-pemrosesan data ini riwayat transaksi yang berbentuk berkas teks akan dilakukan pembersihan data untuk meningkatkan kualitas himpunan data. Dalam tahapan ini berkas teks akan dibersihkan dan dikoversi menjadi berkas excel. Pada proses ini dilakukan penghapusan data informasi perusahaan, alamat perusahaan, nama laporan, keterangan tanggal dan jam laporan dibuat serta halaman laporan. Hal ini dilakukan karena informasi tersebut tidak digunakan dalam proses analisa atau data mining.

\subsection{Transformasi Data}

Tahap transformasi data merupakan proses penyesuaian data yang mengikuti kebutuhan dari tahapan data mining. Data transaksi dalam bentuk file excel dari tahap pra-pemrosesan data diubah menjadi himpunan basis data SQL (Structured Query Language) melalui proses impor pada sistem data mining berbasis web yang dibangun.

\subsection{Data Mining}

Setelah melakukan tahapan prapemrosesan data dan transformasi data yang sesuai untuk penggunaan teknik data mining, maka tahapan selanjutnya adalah proses data mining. Market basket analysis merupakan salah satu bentuk teknik pengaplikasian data mining di bidang pemasaran dan bisnis. Market basket analysis merupakan konsep dalam data mining yang berusaha menemukan asosiasi atau keterkaitan data [4, hal. 5]. Pada awal ditemukannya, konsep ini berkatian dengan barang-barang yang berada di dalam keranjang belanja yang secara langsung menunjukkan tingkah laku konsumen saat berbelanja. Proses ini digunakan untuk melakukan pencarian pola atau informasi dari data terpilih dengan memanfaatkan algoritma ECLAT. Algoritma ini dianggap sesuai digunakan untuk metode pencarian aturan asosiasi. Pada penelitian ini tahap data mining diproses menggunakan aplikasi berbasis web yang dirancang.

Algoritma ECLAT merupakan singkatan dari Equivalence Class Transformation [13, hal. 54]. Algoritma ECLAT menggunakan konsep pencarian depth-first untuk menemukan itemsets yang sering muncul dalam dataset. Menurut Pratiwi [14, hal. II-10] algoritma ECLAT berjalan secara rekursif, proses pencarian itemset berjalan secara berkesinambungan selama sisa itemset masih ditemukan. Algoritma ECLAT terbagi menjadi 4 fase [11, hal. 324] yaitu fase inisialisasi, fase transformasi, fase ansinkron dan fase reduksi akhir. Pada fase inisialisasi, proses yang dilakukan adalah membaca dataset untuk pembentukan kandidat 2-itemset. Selanjutnya pada fase tranformasi, merupakan proser pengubahan dataset menjadi bentuk vertikal. Fase ansinkron adalah pembentukan frequent $k$-itemset sesuai kebutuhan atau tujuan yang ingin di capai. Di fase terakhir yaitu reduksi akhir, seluruh hasil dari fase ansinkron 
dikumpulkan dan dicetak. Gambar 2. menjelaskan bentuk pseudocode algoritma ECLAT [15, hal. 1990]

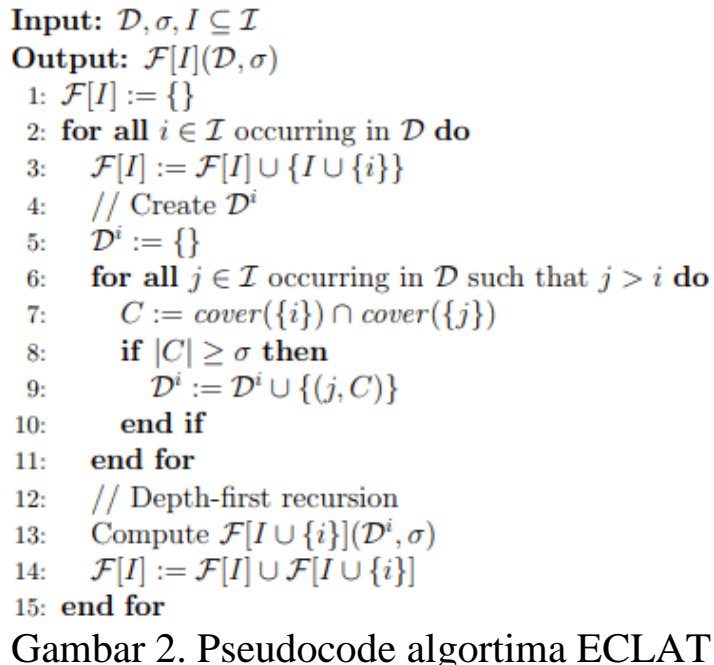

\subsection{Pola Aturan Asosiasi}

Setelah mendapatkan pola penjualan produk dari proses data mining, tahapan berikutnya merupakan proses merepresentasikan hasil yang dicapai dari data mining dalam bentuk yang mudah dimengerti bagi pihak yang berkepentingan. Dalam metode aturan asosiasi, pola informasi yang dihasilkan berupa daftar aturan.

\subsection{Basis Pengetahuan}

Merupakan tahap akhir dari proses data mining yaitu bagaimana memformulasikan keputusan berdasarkan hasil pola aturan asosiasi yang didapat dari keseluruhan proses data mining. Pola aturan asosiasi digunakan sebagai acuan bagi divisi penjualan di PT XYZ cabang Kademangan untuk memberikan rekomendasi produk bagi pelanggan.

\section{HASIL DAN PEMBAHASAN}

\subsection{Perancangan Sistem}

\subsubsection{Usecase Diagram}

Terdapat dua jenis pengguna yaitu Manajer dan Staff yang dapat melakukan beberapa aktifitas pada aplikasi yang dibangun. Aktifitas-aktifitas tersebut akan dijabarkan dalam bentuk diagram usecase pada Gambar 3.

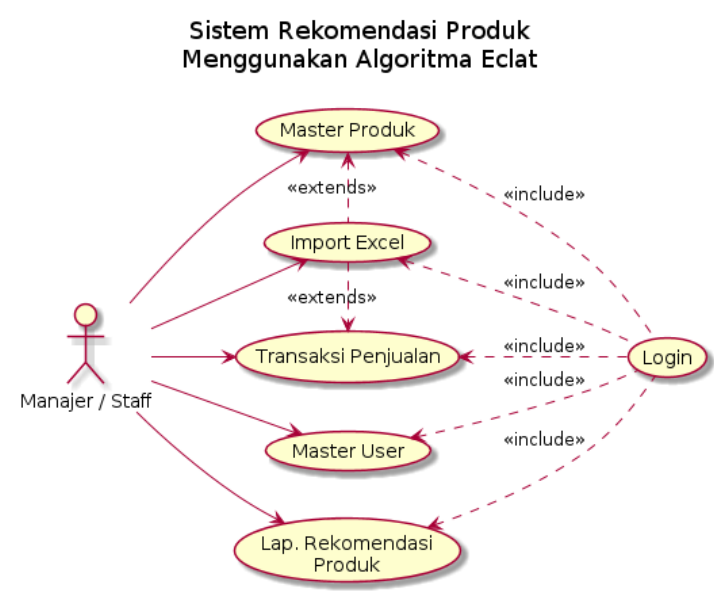

Gambar 3. Usecase diagram

\subsubsection{Class Diagram}

Class diagram menampilkan kelaskelas yang terdapat pada sistem beserta hubungan antar kelas lainnya. Pada sistem ini terdapat enam class diagram yang saling terhubung yang dapat dilihat pada Gambar 4. 

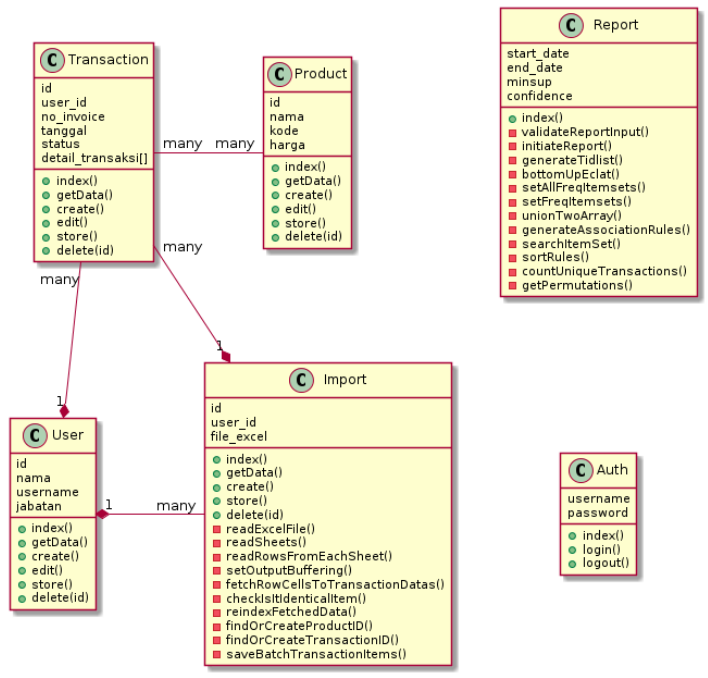

Gambar 4. Class diagram pada sistem

\subsubsection{Struktur Database}

Struktur database beserta relasi antar tabel yang terdapat pada sistem ditampilkan pada Gambar 5.

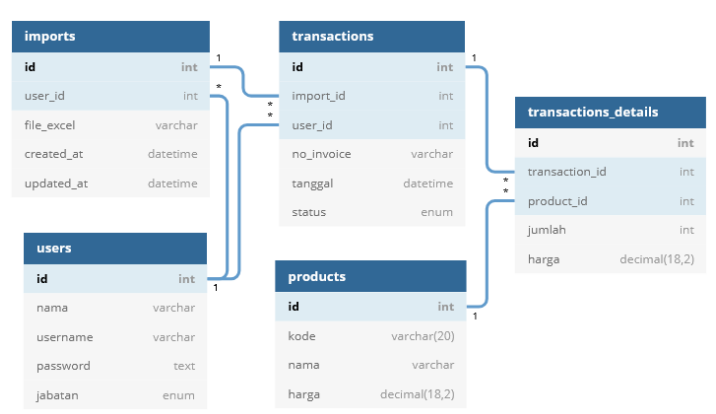

Gambar 5. Struktur database

\subsection{Hasil Pengujian Sistem}

\subsubsection{Tampilan Login}

Gambar 6. menunjukkan tampilan halaman awal ketika aplikasi dijalankan. Pada tampilan ini terdapat form login yang perlu manajer atau staff lewati sebelum masuk kedalam sistem yaitu dengan memasukkan username dan kata sandi.

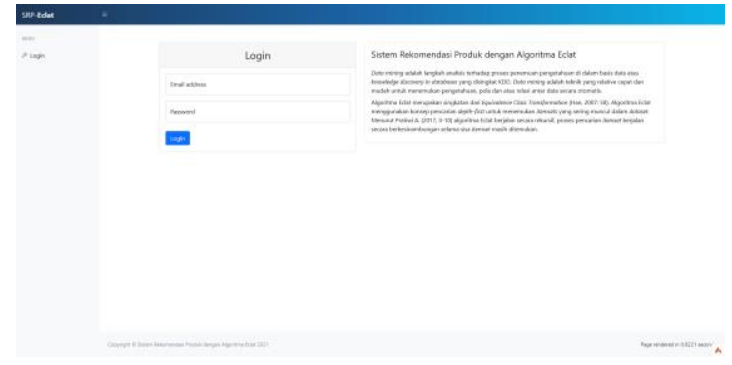

Gambar 6. Tampilan awal sistem

\subsubsection{Tampilan Halaman Dashboard}

Gambar 7. menunjukkan tampilan halaman utama setelah berhasil melakukan proses login. Pada tampilan ini terdapat Menu dashboard, master pengguna, master produk, transaksi penjualan impor excel transaksi penjualan dan lap. rekomendasi produk. Pada halaman ini juga menampilkan ringkasan jumlah pengguna, jumlah transaksi penjualan dan jumlah barang.

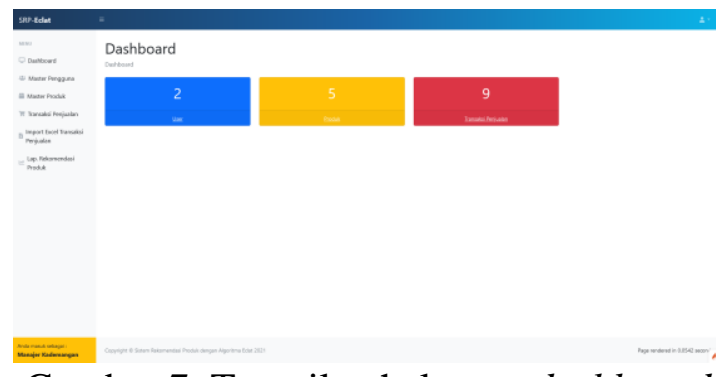

Gambar 7. Tampilan halaman dashboard

\subsubsection{Tampilan Master Pengguna}

Halaman master pengguna digunakan untuk memanajemen data pengguna sistem ini. Pada halaman ini terdapat fungsi tambah pengguna, ubah pengguna dan hapus pengguna. 


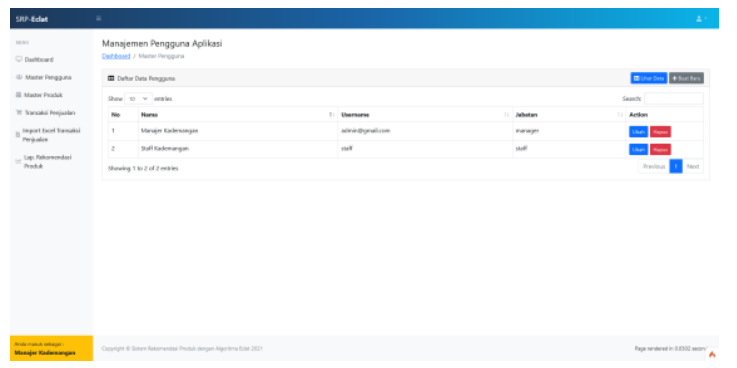

Gambar 8. Tampilan halaman master pengguna

\subsubsection{Tampilan Master Produk}

Halaman master produk digunakan untuk memanajemen data produk. Pada halaman ini manajer atau staff dapat melakukan proses tambah produk, ubah produk dan hapus produk.

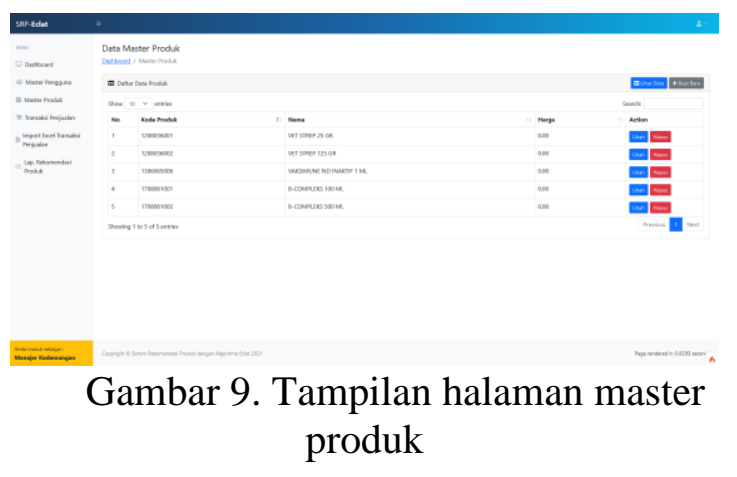

\subsubsection{Tampilan Transaksi Penjualan}

Halaman transaksi penjualan digunakan untuk memanajemen data riwayat transaksi penjualan. Pada halaman ini manajer atau staff dapat melakukan proses tambah transaksi, ubah transaksi dan hapus riwayat transaksi.

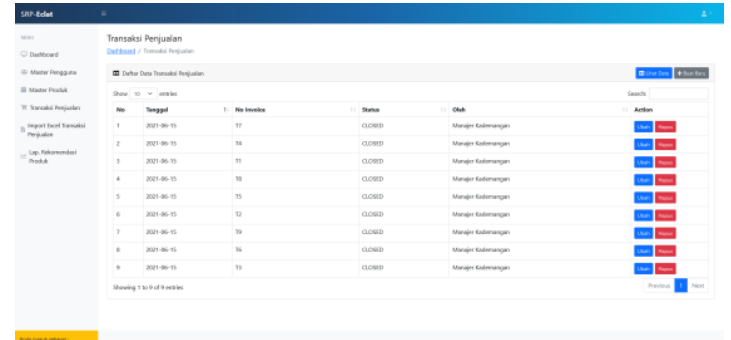

Gambar 10. Tampilan halaman transaksi penjualan

\subsubsection{Tampilan Impor Excel Transaksi Penjualan}

Halaman impor excel transaksi penjualan digunakan untuk memanajemen data berkas excel riwayat transaksi penjualan. Berkas yang diunggah akan melalui proses pembacaan berkas dan transformasi data agar dapat digunakan pada proses data mining.

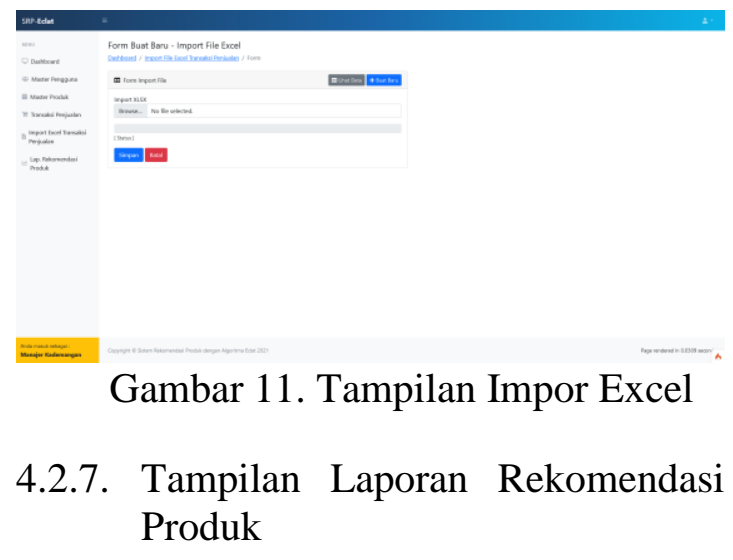

Halaman laporan rekomendasi produk digunakan untuk mengolah data riwayat transaksi penjualan dengan memanfaatkan data mining dan algoritma ECLAT. 


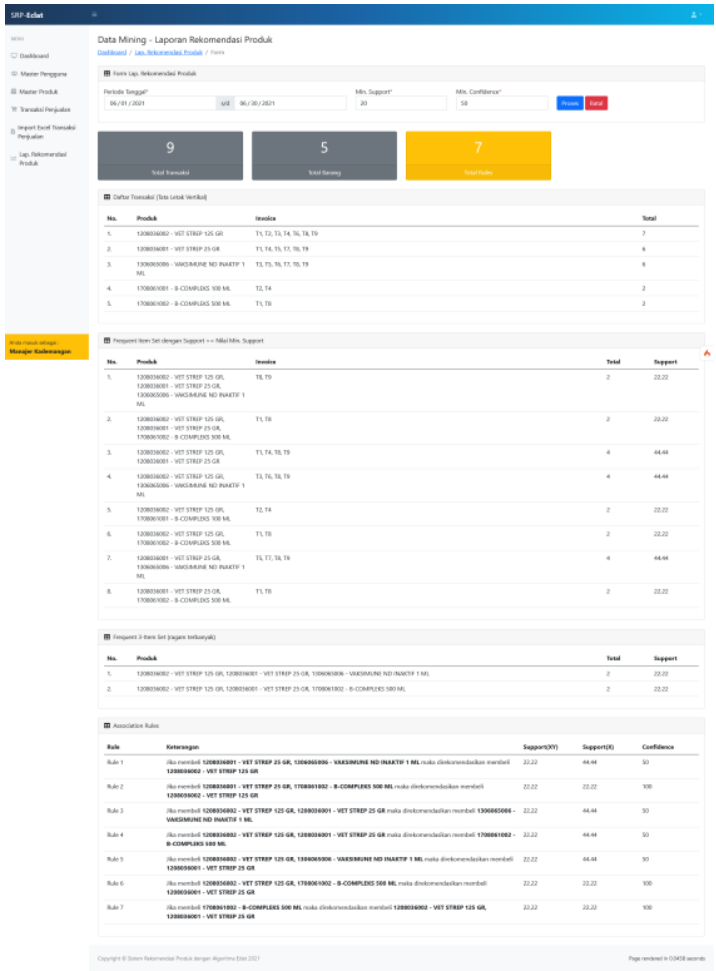

Gambar 12. Tampilan laporan rekomendasi produk

\subsection{Perhitungan}

4.3.1. Perhitungan Algoritma ECLAT dengan data sampel 10 transaksi

Pengujian dilakukan dengan menggunakan parameter min. support 20 dan confidence 50 yang sudah dipersiapkan sebelumnya. Tabel 1 . menampilkan data sampel 10 transaksi penjualan.

Tabel 1. Data sampel perhitungan manual

\begin{tabular}{ll}
\hline Transaksi & \multicolumn{1}{c}{ Produk } \\
\hline 60001 & VET STREP 125 GR, VET \\
& STREP 25 GR, B-COMPLEKS \\
& 500 ML \\
\hline 60002 & VET STREP 125 GR, B- \\
& COMPLEKS 100 ML \\
\hline
\end{tabular}

\begin{tabular}{ll}
\hline 60003 & VET STREP 125 GR, \\
& VAKSIMUNE ND INAKTIF 1 \\
& ML \\
\hline 60004 & VET STREP 125 GR, VET \\
& STREP 25 GR, B-COMPLEKS \\
& 100 ML \\
\hline 60005 & VET STREP 25 GR, \\
& VAKSIMUNE ND INAKTIF 1 \\
& ML \\
\hline 60006 & VET STREP 125 GR, \\
& VAKSIMUNE ND INAKTIF 1 \\
& ML \\
\hline 60007 & VET STREP 25 GR, \\
& VAKSIMUNE ND INAKTIF 1 \\
& ML \\
\hline 60008 & VET STREP 125 GR, VET \\
& STREP 25 GR, VAKSIMUNE \\
& ND INAKTIF 1 ML, B- \\
& COMPLEKS 500 ML \\
\hline 60009 & VET STREP 125 GR, VET \\
& STREP 25 GR, VAKSIMUNE \\
& ND INAKTIF 1 ML \\
\hline 60010 & VAKSIMUNE ND INAKTIF 1 \\
& ML, B-COMPLEKS 500 ML \\
\hline (Sumber: PT XYZ, 2021)
\end{tabular}

Dari data tersebut proses selanjutnya adalah dengan mengubah struktur data transaksi menjadi vertikal dan membuat himpunan untuk setiap produk. Himpunan \{ VET STREP 125 GR \} merupakan daftar transaksi yang mengandung produk $\{$ VET STREP 125 GR $\}$ atau disebut juga dengan 1-itemset. K-itemset merupakan itemset yang berisi k produk, contoh himpunan \{ VAKSIMUNE ND INAKTIF $1 \mathrm{ML}$, BCOMPLEKS $500 \mathrm{ML}$ \} disebut dengan 2itemset dan \{ VET STREP 125 GR, VET STREP 25 GR, B-COMPLEKS 500 ML \} disebut dengan 3-itemset. 
Tabel 2. Struktur data vertikal

\begin{tabular}{llc}
\hline \multicolumn{1}{c}{ Produk } & \multicolumn{1}{c}{ Transaksi } & Support \\
\hline VET STREP 125 & 60001,60002, & 70 \\
GR & 60003,60004, & \\
& 60006,60008, & \\
& 60009 & \\
\hline VET STREP 25 & 60001,60004, & 60 \\
GR & 60005,60007, & \\
& 60008,60009 & \\
\hline VAKSIMUNE & 60003,60005, & 70 \\
ND INAKTIF 1 & 60006,60007, & \\
ML & 60008,60009, & \\
& 60010 \\
\hline B-COMPLEKS & 60002,60004 & 20 \\
100 ML & & \\
\hline B-COMPLEKS & 60001,60008, & 30 \\
500 ML & 60010 & \\
\hline
\end{tabular}

Dari Tabel 2. kemudian membuat 2itemset dengan melakukan persimpangan himpunan $\{a\}$ dengan daftar himpunan yang lain sehingga menghasilkan himpunan $\{a, b\}\{a, c\}\{a, d\}$ dan seterusnya hingga tidak ada lagi pasangan item-tidset yang dapat digabungkan. Setiap himpunan 2-itemset yang melewati minimum support 20 diproses pada tahap selanjutnya.

Tabel 3. Hasil perhitungan 2-itemset

\begin{tabular}{lcc}
\hline \multicolumn{1}{c}{ Produk } & Transaksi & Support \\
\hline VET STREP 125 GR, & 4 & 40 \\
VAKSIMUNE ND & & \\
INAKTIF 1 ML & & \\
\hline VET STREP 125 GR, & 4 & 40 \\
VET STREP 25 GR & & \\
\hline VET STREP 125 GR, & 2 & 20 \\
B-COMPLEKS 500 & & \\
ML & & \\
\hline VET STREP 125 GR, & 2 & 20 \\
B-COMPLEKS 100 \\
ML
\end{tabular}

\begin{tabular}{lll}
\hline VAKSIMUNE ND & 4 & 40 \\
INAKTIF 1 ML, VET & & \\
STREP 25 GR & & 20 \\
\hline VAKSIMUNE ND & 2 & \\
INAKTIF 1 ML, B- & & \\
COMPLEKS 500 ML & & 20 \\
\hline VET STREP 25 GR, & 2 & \\
B-COMPLEKS 500 & & \\
ML & & \\
\hline
\end{tabular}

Seperti pada tahap sebelumnya, setiap 2-itemset yang ditemukan dan memenuhi kondisi minimum support dengan melakukan persimpangan himpunan $\{a, b\}$ dengan himpunan $\{a, c\}$ dan himpunan yang lain sehingga menghasilkan himpunan $\{a, b, c\}$ dan seterusnya dan dihitung minimum support-nya. Tabel 4. menunjukan hasil dari proses rekursif 3itemset yang memenuhi nilai support 20 . Proses ini berulang, dengan $\mathrm{k}$ bertambah 1 setiap kali, hingga tidak ada item atau tidak ada kandidat item yang dapat ditemukan dan atau memenuhi minimum support.

Tabel 4. Hasil perhitungan 3-itemset

\begin{tabular}{lcc}
\hline \multicolumn{1}{c}{ Produk } & Transaksi & Support \\
\hline VET STREP 125 GR, & 2 & 20 \\
VAKSIMUNE ND & & \\
INAKTIF 1 ML, VET & & \\
STREP 25 GR & & \\
\hline VET STREP 125 GR, & 2 & 20 \\
VET STREP 25 GR, & & \\
B-COMPLEKS 500 & & \\
ML & & \\
\hline
\end{tabular}

Tabel 5. Hasil perhitungan 4-itemset tidak memenuhi min. support

\begin{tabular}{ccc}
\hline Produk & Transaksi & Support \\
\hline VET STREP 25 GR, & 1 & 10 \\
VET STREP 125 GR, & & \\
\hline
\end{tabular}


VAKSIMUNE ND

INAKTIF 1 ML, B-

COMPLEKS $500 \mathrm{ML}$

Setelah pola frekuensi tertinggi dari produk ditemukan maka dilanjutkan dengan mencari aturan asosiasi dengan menghitung nilai confidence-nya. Tabel 6 . menunjukkan daftar aturan asosiasi yang dihasilkan dari 3-itemset \{ VET STREP 125 GR, VAKSIMUNE ND INAKTIF 1 ML, VET STREP 25 GR \} dan \{VET STREP 125 GR, VET STREP 25 GR, BCOMPLEKS 500 ML \}. Untuk setiap aturan asosiasi yang tidak memenuhi minimum confidence dilakukan penghapusan.

Tabel 6. Hasil aturan asosiasi

\begin{tabular}{lcc}
\hline \multicolumn{1}{c}{ Aturan } & AB/A & Conf. \\
\hline$\{$ VET STREP 125 GR, B- & $20 / 20$ & $100 \%$ \\
COMPLEKS 500 ML $\} \rightarrow\{$ & & \\
VET STREP 25 GR \} & & \\
\hline$\{$ VET STREP 25 GR, B- & $20 / 20$ & $100 \%$ \\
COMPLEKS 500 ML $\} \rightarrow\{$ & & \\
VET STREP 125 GR \} & & \\
\hline$\{$ B-COMPLEKS 500 ML $\}$ & $20 / 30$ & $66,66 \%$ \\
$\rightarrow$ \{ VET STREP 125 GR, & & \\
VET STREP 25 GR \} & & \\
\hline VET STREP 125 GR, & $20 / 40$ & $50 \%$ \\
VAKSIMUNE ND & & \\
INAKTIF 1 ML $\} \rightarrow\{$ VET & & \\
STREP 25 GR \} & & \\
\hline$\{$ VET STREP 125 GR, & $20 / 40$ & $50 \%$ \\
VET STREP 25 GR $\} \rightarrow\{$ & & \\
VAKSIMUNE ND & & \\
INAKTIF 1 ML \} & & \\
\hline$\{$ VAKSIMUNE ND & $20 / 40$ & $50 \%$ \\
INAKTIF 1 ML, VET & & \\
STREP 25 GR $\} \rightarrow\{$ VET & & \\
STREP 125 GR $\}$ & & \\
\hline
\end{tabular}

\begin{tabular}{|c|c|c|}
\hline $\begin{array}{l}\{\text { VET STREP } 125 \mathrm{GR}, \\
\text { VET STREP } 25 \mathrm{GR}\} \rightarrow\{ \\
\text { B-COMPLEKS } 500 \mathrm{ML}\}\end{array}$ & $20 / 40$ & $50 \%$ \\
\hline $\begin{array}{l}\{\text { VET STREP } 25 \text { GR }\} \rightarrow\{ \\
\text { VET STREP } 125 \text { GR, } \\
\text { VAKSIMUNE ND } \\
\text { INAKTIF } 1 \text { ML }\}\end{array}$ & $20 / 60$ & $33,33 \%$ \\
\hline $\begin{array}{l}\{\text { VET STREP } 25 \mathrm{GR}\} \rightarrow\{ \\
\text { VET STREP } 125 \mathrm{GR}, \mathrm{B}- \\
\text { COMPLEKS } 500 \mathrm{ML}\}\end{array}$ & $20 / 60$ & $33,33 \%$ \\
\hline $\begin{array}{l}\{\text { VET STREP } 125 \text { GR }\} \rightarrow \\
\{\text { VAKSIMUNE ND } \\
\text { INAKTIF } 1 \text { ML, VET } \\
\text { STREP } 25 \text { GR }\}\end{array}$ & $20 / 70$ & $28,57 \%$ \\
\hline $\begin{array}{l}\{\text { VAKSIMUNE ND } \\
\text { INAKTIF } 1 \mathrm{ML}\} \rightarrow\{\text { VET } \\
\text { STREP } 125 \mathrm{GR}, \mathrm{VET} \\
\text { STREP } 25 \mathrm{GR}\}\end{array}$ & $20 / 70$ & $28,57 \%$ \\
\hline $\begin{array}{l}\{\text { VET STREP } 125 \mathrm{GR}\} \rightarrow \\
\{\text { VET STREP } 25 \mathrm{GR}, \mathrm{B}- \\
\text { COMPLEKS } 500 \mathrm{ML}\}\end{array}$ & $20 / 70$ & $28,57 \%$ \\
\hline
\end{tabular}

Tabel 7. Hasil aturan asosiasi yang memenuhi confidence 50\%

\begin{tabular}{|c|c|c|c|}
\hline$\#$ & Aturan & $\mathbf{A B} / \mathbf{A}$ & Conf. \\
\hline 1 & $\begin{array}{l}\{\text { VET STREP } 125 \text { GR, } \\
\text { B-COMPLEKS } 500 \mathrm{ML} \\
\} \rightarrow\{\text { VET STREP } 25 \\
\text { GR }\}\end{array}$ & $20 / 20$ & $100 \%$ \\
\hline 2 & $\begin{array}{l}\{\text { VET STREP } 25 \text { GR, } \\
\text { B-COMPLEKS } 500 \text { ML } \\
\} \rightarrow\{\text { VET STREP } 125 \\
\text { GR }\}\end{array}$ & $20 / 20$ & $100 \%$ \\
\hline 3 & $\begin{array}{l}\{\text { B-COMPLEKS } 500 \\
\text { ML }\} \rightarrow\{\text { VET STREP } \\
125 \text { GR, VET STREP } 25 \\
\text { GR }\}\end{array}$ & $20 / 30$ & $66,66 \%$ \\
\hline 4 & $\begin{array}{l}\{\text { VET STREP } 125 \text { GR, } \\
\text { VAKSIMUNE ND } \\
\text { INAKTIF } 1 \mathrm{ML}\} \rightarrow\{ \\
\text { VET STREP } 25 \text { GR }\}\end{array}$ & $20 / 40$ & $50 \%$ \\
\hline 5 & $\begin{array}{l}\{\text { VET STREP } 125 \text { GR, } \\
\text { VET STREP } 25 \text { GR }\} \rightarrow \\
\{\text { VAKSIMUNE ND } \\
\text { INAKTIF } 1 \text { ML }\}\end{array}$ & $20 / 40$ & $50 \%$ \\
\hline
\end{tabular}




\begin{tabular}{llll}
\hline 6 & \{ VAKSIMUNE ND & 20/40 & $50 \%$ \\
& INAKTIF 1 ML, VET & & \\
& STREP 25 GR \} $\rightarrow\{$ & & \\
& VET STREP 125 GR \} & & \\
\hline 7 & \{ VET STREP 125 GR, & $20 / 40$ & $50 \%$ \\
& VET STREP 25 GR \} $\rightarrow$ & & \\
& \{ B-COMPLEKS 500 & & \\
& ML $\}$ & \\
\hline
\end{tabular}

\subsubsection{Perhitungan Algoritma ECLAT} Menggunakan Sistem dengan Data Sampel 10 Transaksi

Sistem yang telah dibuat perlu dilakukan uji coba dengan data yang sama untuk mengecek keakuratan hasilnya. Sistem diuji dengan parameter minimum support 20 dan confidence 50. Proses pengubahan struktur data transaksi menjadi vertikal dan membuat himpunan untuk setiap produk pada sistem dapat dilihat pada Gambar 14.

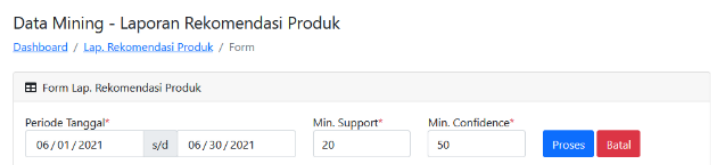

Gambar 13. Memasukkan parameter min. support dan min. confidence

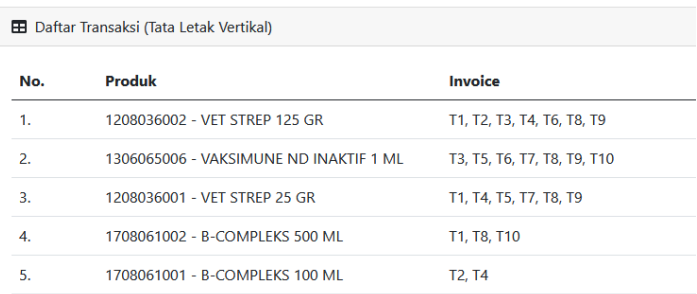

Gambar 14. Tampilan Data Transaksi yang telah diolah menjadi Tata Letak Vertikal
Setelah sistem mengubah struktur data transaksi menjadi vertikal dan membuat 1itemset, maka secara otomatis dan rekursif, sistem menjalankan proses algoritma ECLAT untuk menemukan frequent itemset yang memenuhi kriteria minimum support. Gambar 15. menunjukkan hasil yang diperoleh.

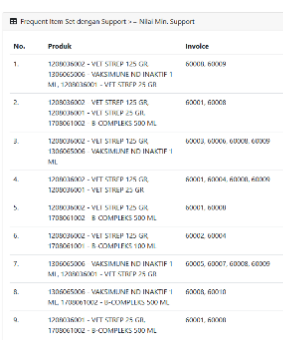

Gambar 15. Frequent k-itemset hasil dari proses algoritma ECLAT

Setelah proses rekursif tidak menemukan lagi pasangan item-tidset yang dapat digabungkan, sistem akan memilih frequent $k$-itemset tertinggi yang akan digunakan untuk membuat aturan asosiasi. Gambar 16. menampilkan daftar itemset yang dipilih oleh sistem. Sistem menghasilkan 7 aturan asosiasi yang memenuhi kriteria confidence 50.

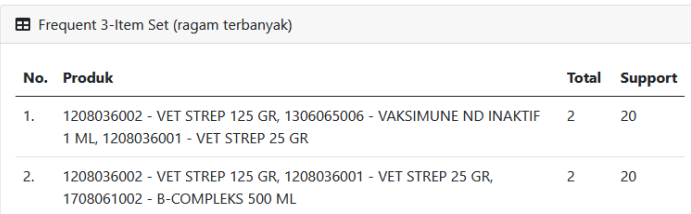

Gambar 16. Frequent 3-itemset pilihan sistem 


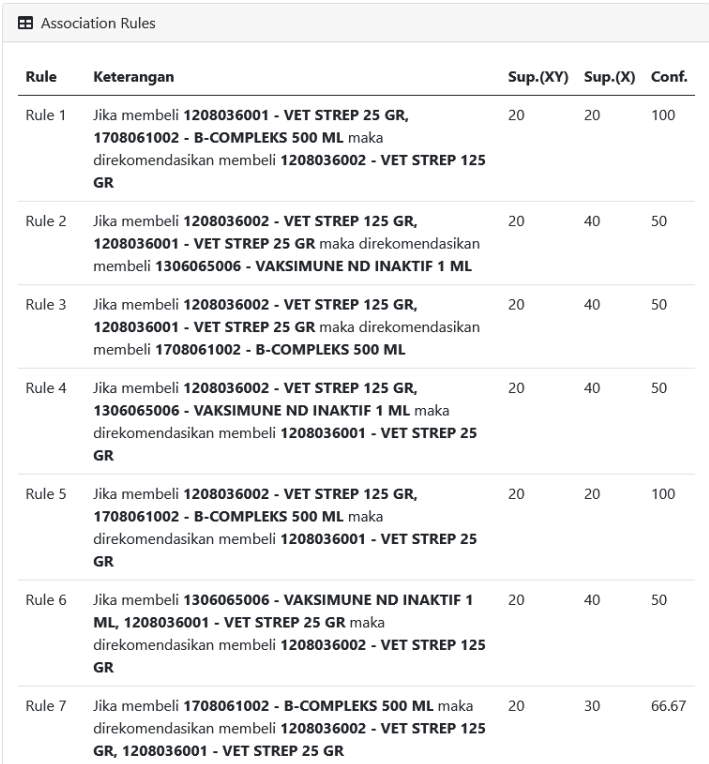

Gambar 17. Analisis Rekomendasi

Produk yang dihasilkan oleh Sistem

\subsubsection{Perhitungan Algoritma ECLAT} menggunakan sistem dengan data riil

Perhitungan algoritma ECLAT dilanjutkan dengan menggunakan data riil riwayat transaksi penjualan tahun 20182020 yang sudah melalui proses prapemrosesan data. Data riil dalam bentuk file excel melalui tahap transformasi data menghasilkan 14.617 riwayat transaksi. Perhitungan dibatasi menjadi per tahun, dan menghasilkan hasil terbaik dengan minimum support $1 \%$ dan minimum confidence $50 \%$.

Tabel 8. Hasil aturan asosiasi pada riwayat transaksi tahun 2018

\begin{tabular}{lllll}
\hline Rule & Aturan & $\begin{array}{l}\text { Sup } \\
(\mathbf{X Y})\end{array}$ & $\begin{array}{l}\text { Sup } \\
(\mathbf{X})\end{array}$ & Conf \\
\hline 1 & Jika membeli & 1.19 & 1.28 & 92.97 \\
& $\mathbf{1 7 0 8 0 6 1 0 0 2}$ - B- & & & \\
\hline
\end{tabular}

\begin{tabular}{lllll}
\hline COMPLEKS 500 & & & \\
ML maka & & & \\
direkomendasikan & & & \\
membeli & & & \\
1208036002 - & & & \\
VET STREP 125 & & & \\
GR & & & \\
\hline 2 & Jika membeli & 1.19 & 1.4 & 85 \\
& 1208036002 - & & & \\
VET STREP 125 & & & \\
GR maka & & & \\
direkomendasikan & & & \\
membeli & & & \\
1708061002 - B- & & & \\
COMPLEKS 500 & & \\
ML & \\
\hline
\end{tabular}

Tabel 9. Hasil aturan asosiasi pada riwayat transaksi tahun 2019

\begin{tabular}{lllll}
\hline Rule & Aturan & $\begin{array}{l}\text { Sup } \\
(\mathbf{X Y})\end{array}$ & $\begin{array}{l}\text { Sup } \\
(\mathbf{X})\end{array}$ & Conf \\
\hline & Jika membeli & & & \\
& 1708061002 - B- & & & \\
& COMPLEKS 500 & & & \\
& ML maka & & & \\
1 & direkomendasikan & 1.21 & 1.27 & 95.28 \\
& membeli & & & \\
& 1208036002 - & & & \\
& VET STREP 125 & & & \\
& GR & & & \\
& Jika membeli & & & \\
& 1208036002 - & & & \\
& VET STREP 125 & & & \\
& GR maka & & & \\
direkomendasikan & 1.21 & 1.42 & 85.21 \\
& membeli & & & \\
& 1708061002 - B- & & \\
COMPLEKS 500 & & & \\
ML & & & \\
\hline
\end{tabular}

Tabel 10. Hasil aturan asosiasi pada riwayat transaksi tahun 2020

\begin{tabular}{|c|c|c|c|c|}
\hline Rule & Aturan & $\begin{array}{l}\text { Sup } \\
\text { (XY) }\end{array}$ & $\begin{array}{l}\text { Sup } \\
\text { (X) }\end{array}$ & Conf \\
\hline
\end{tabular}




\begin{tabular}{|c|c|c|c|c|}
\hline 1 & $\begin{array}{l}\text { Jika membeli } \\
\text { 1708061002 - B- } \\
\text { COMPLEKS 500 } \\
\text { ML maka } \\
\text { direkomendasikan } \\
\text { membeli } \\
\text { 1208036002 - } \\
\text { VET STREP } 125 \\
\text { GR } \\
\end{array}$ & 1.34 & 1.55 & 86.45 \\
\hline 2 & $\begin{array}{l}\text { Jika membeli } \\
\text { 1208036002 - } \\
\text { VET STREP } 125 \\
\text { GR maka } \\
\text { direkomendasikan } \\
\text { membeli } \\
\text { 1708061002 - B- } \\
\text { COMPLEKS 500 } \\
\text { ML }\end{array}$ & 1.34 & 1.65 & 81.21 \\
\hline 3 & $\begin{array}{l}\text { Jika membeli } \\
\text { 1208036001 - } \\
\text { VET STREP } 25 \\
\text { GR maka } \\
\text { direkomendasikan } \\
\text { membeli } \\
\text { 1708061001 - B- } \\
\text { COMPLEKS } 100 \\
\text { ML }\end{array}$ & 1.2 & 1.53 & 78.43 \\
\hline 4 & $\begin{array}{l}\text { Jika membeli } \\
\text { 1708061001 - B- } \\
\text { COMPLEKS } 100 \\
\text { ML maka } \\
\text { direkomendasikan } \\
\text { membeli } \\
\text { 1208036001 - } \\
\text { VET STREP } 25 \\
\text { GR }\end{array}$ & 1.2 & 1.53 & 78.43 \\
\hline 5 & $\begin{array}{l}\text { Jika membeli } \\
\text { 1306065006 - } \\
\text { VAKSIMUNE } \\
\text { ND INAKTIF 1 } \\
\text { ML maka } \\
\text { direkomendasikan } \\
\text { membeli } \\
\text { 1303065002 - } \\
\text { VAKSIMUNE } \\
\text { ND LS IB 1000 } \\
\text { DS }\end{array}$ & 1.12 & 1.98 & 56.57 \\
\hline
\end{tabular}

\section{SIMPULAN}

Berdasarkan pembahasan, dapat diperoleh beberapa kesimpulan, yaitu sebagai berikut.

a. Rancangan sistem rekomendasi produk yang dirancang dapat melakukan transformasi data riwayat transaksi yang sebelumnya dalam bentuk berkas excel menjadi bentuk basis data dan diolah dengan data mining.

b. Algoritma ECLAT dalam rancangan sistem rekomendasi produk berdasarkan data riwayat penjualan PT XYZ berhasil diterapkan pada modul Lap. Rekomendasi Produk dan berdasarkan hasil uji sampel antara perhitungan sistem dengan perhitungan manual, memiliki keakuratan $100 \%$.

c. Hasil analisis dari sistem rekomendasi produk berdasarkan data riwayat penjualan PT XYZ, yaitu dari 14.617 riwayat transaksi minimum support tertinggi untuk menemukan kombinasi $k$-itemset adalah $1 \%$. Riwayat transaksi tahun 2018 menghasilkan 2 aturan asosiasi, tahun 2019 menghasilkan 2 aturan asosiasi dan tahun 2020 menghasilkan 5 aturan asosiasi. Setiap aturan asosiasi yang muncul memiliki nilai confidence yang kuat yakni diatas 50\%. Bedasarkan kategori produk, ketika pelanggan melakukan pembelian obat injeksi maka memiliki kemungkinan untuk sekaligus membeli vitamin injeksi dan sebaliknya. Ketika pelanggan melakukan pembelian vaksin inaktif ( $k$ ill) maka memiliki 
kemungkinan untuk sekaligus membeli vaksin live.

Penelitian selanjutnya yang dapat dilakukan antara lain dengan menggunakan algoritma turunan dari ECLAT dan menambah fitur untuk mencetak hasil laporan yang didapatkan sehingga laporan dapat digunakan oleh pihak yang berkepentingan dan atau manajemen PT XYZ tanpa harus menjalankan proses laporan setiap waktu.

\section{DAFTAR PUSTAKA}

[1] PT XYZ, "Wawancara PT XYZ," Blitar, 2021.

[2] T. Subianto, "Studi Tentang Perilaku Konsumen Beserta Implikasinya Terhadap Keputusan Pembelian," J. Ekon. Mod., vol. 3, no. 2, hal. 165-182, 2007.

[3] N. F. H. Lestari, "Pola Perilaku Membeli Produk Kebutuhan Rumah Tangga (Pangan dan Non Pangan) di Pasar Modern Pada Konsumen Wanita Dewasa Tengah di Kota Karawang," Universitas Brawijaya, 2014.

[4] D. Suyanto, Data Mining untuk Klasifikasi dan Klasterisasi Data. Bandung: Informatika Bandung, 2017.

[5] Sulastri, E. Zuliarso, dan Y. Anis, "Implementasi Algoritma Apriori dan Algoritma Eclat pada Ahass Akmal Jaya Purwodadi," J. Din., vol. 22, hal. 49-56, 2017.

[6] K. N. Wijaya, "Analisis Pola Frekuensi Keranjang Belanja dengan Perbandingan Algoritma Fp-Growth (Frequent Pattern Growth) dan Eclat pada Minimarket," J. Tek. Inform. dan Sist. Inf., vol. 7, no. Agustus 2020, hal. 364-373, 2020.

[7] Sudaryono, Manajemen

Pemasaran: Teori dan

Implementasi. Yogyakarta: CV. Andi Offset, 2016.

[8] S. D. Pratiwi dan L. Suriani, "Strategi Pemasaran Produk Rangka Atap Baja Ringan Pada PT. Hari Rezeki Kita Semua Pekanbaru," J. Valuta, vol. 3, no. 2, hal. 241-275, 2017, [Daring]. Tersedia pada: https://journal.uir.ac.id/index.php/v aluta/article/view/2078.

[9] M. Rasyaf, Beternak Ayam Kampung, Cet. 1. Jakarta: Penebar Swadaya, 2011.

[10] G. Hidayat, "Manajemen Sarana Produksi Ternak pada Program Keahlian Budidaya Ternak SMK Negeri 1 Pandak Bantul Yogyakarta," Univesitas Negeri Yogyakarta, 2011.

[11] M. J. Zaki, S. Parthasarathy, dan W. Li, "A Localized Algorithm for Parallel Association Mining A Localized Algorithm for Parallel Association Mining," no. June 2015, 1997, doi: $10.1145 / 258492.258524$.

[12] U. Fayyad, G. Piatetsky-Shapiro, dan P. Smyth, "From Data Mining to Knowledge Discovery in 
Databases," AI Magazine, hal. 17(3), 37, 1996.

[13] J. Han, H. Cheng, D. Xin, X. Yan, dan S. Barbara, "Frequent pattern mining : Current status and future directions Frequent pattern mining : current status and future," Data Min. Knowl. Discov., vol. 1, no. 5, hal. 55-86, 2007, doi:

10.1007/s10618-006-0059-1.

[14] A. Pratiwi, "Penerapan Algoritma Declat Dalam Identifikasi Adverse Event Pada Obat Antihipertensi Berdasarkan Kelompok Umur dan Jenis Kelamin," Universitas Islam
Negeri Sultan Syarif Kasim Riau, 2017.

[15] F. Kayaalp, "Performance Comparison of Association Rule Algorithms with SPMF on Automotive Industry Data," Düzce Univ. J. Sci. Technol., no. July, hal. 1985-2000, 2019, [Daring].

Tersedia pada:

https://www.researchgate.net/publi cation/334825343_Performance_C omparison_of_Association_Rule_ Algorithms_with_SPMF_on_Auto motive_Industry_Data. 